This version: August 6, 2008

\title{
Organizational Structure and the Diversification Discount: Evidence from Commercial Banking
}

\author{
Peter G. Klein \\ Marc R. Saidenberg \\ Journal of Industrial Economics, forthcoming.
}

\begin{abstract}
This paper provides evidence on organizational structure, geographic diversification, and performance at bank holding companies (BHCs). First, we show that a BHC's member banks benefit from access to the parent organization's internal capital market. Second, we ask if the benefits of internal capital markets are best realized within loosely structured, decentralized organizations or more consolidated, centralized firms. We find that BHCs with many subsidiaries are less profitable and have lower $q$ ratios than similar BHCs with fewer subsidiaries. However, because we study multi-unit firms in a single industry, our results suggest that the valuation discount reported in the diversification literature in empirical corporate finance reflects not only industry diversification, but also organizational structure.
\end{abstract}

JEL: L22, G21

Corresponding author: Peter G. Klein, Contracting and Organizations Research Institute, University of Missouri, 135 Mumford Hall, Columbia, MO 65211, 573-882-7008, 573-882-3958 (fax), pklein@missouri.edu

We are grateful to Peter Carstensen, Tom Gilligan, Sandy Klein, Larry Lang, Eric Powers, Tara Rice, Dan Rubinfeld, Joe Sinkey, Phil Strahan, Ken Corts (the editor), and two anonymous referees for helpful comments and suggestions and to Per Bylund for research assistance. 


\section{Introduction}

Recent years have witnessed a healthy debate over the value and performance of diversified companies. Is diversification efficient? Under what circumstances do diversified firms trade at a discount -i.e., have lower $q$ ratios - than more specialized firms, and why? Seemingly lost in the search for a diversification discount, however, is a related question: What is being discounted? Consider the benefits and costs suggested in the diversification literature. Potential benefits include access to internal capital markets and more efficient redeployment of distressed assets (Alchian, 1969; Williamson, 1975; Stein, 1997). Potential costs include inefficient rent-seeking (Scharfstein and Stein, 2000), bargaining problems (Rajan, Servaes, and Zingales, 2000), and bureaucratic rigidity (Shin and Stulz, 1998). Yet these benefits and costs have little to do with industry or geographic diversification per se. Instead, they apply to the management of any multi-unit organization, even if its activities do not span different industries or regions. In evaluating the discount literature it is thus important to distinguish the effects of industry or geographic diversification from the effects of organizational structure. If there is a diversification discount, then investors may be discounting organizational complexity, not diversification. ${ }^{1}$

We distinguish the effects of organizational structure from the effects of diversification by studying multi-unit firms within a single industry, commercial banking. Our analysis focuses on the 1990-94 period, immediately before the implementation of the Riegle-Neal Interstate Banking and Branching Efficiency Act of 1994. During this period, banks were forbidden from branching across state lines, so a bank wishing to operate in multiple states was required to establish a bank holding company with independently chartered subsidiaries in each state. (Each subsidiary had to maintain its own capital reserves and satisfy state and national regulatory requirements.) This resulted in organizations that are narrowly focused - they operate in a single industry, producing a single "product" (financial services) — yet have complex, multidivisional structures. Multibank bank holding companies (MBHCs) are geographically diversified, but only very narrowly diversified in the product space. ${ }^{2}$ These legal restrictions facilitate a relatively 
"clean" test of the effects of organizational form on firm characteristics and performance. If multi-unit banking organizations have lower $q$ ratios than more focused banking organizations, then the diversification discount reported in some studies of industrial firms may be at least partly an organizational-structure discount.

Our argument proceeds in two steps. First, we study a panel of U.S. commercial banks to see how holding-company affiliation affects lending, capital, and profitability. Following Diamond (1984) and Froot and Stein (1998) we assume that financial firms, like industrial companies, are subject to external financing constraints, so that all positive NPV projects (loans) cannot be funded through bank deposits and externally generated capital. Membership in a holding company gives a bank access to the parent organization's capital and liquidity, potentially allowing it to take advantage additional lending opportunities. We find that membership in a holding company allows banks to do more lending, and hold less capital, than unaffiliated banks, consistent with recent literature on bank internal capital markets. Holding-company affiliates are also more profitable than unaffiliated banks, though this could be a selection effect or the result of unobserved heterogeneity. On the whole, the evidence is consistent with an efficiency explanation for geographic expansion stressing internal-capital-market advantages.

Second, we ask if the structure of the internal capital market matters. Are the benefits of intra-firm resource allocation best realized within a loosely structured, decentralized organizational structure or a more consolidated, centralized firm? To find out, we use a panel of publicly traded bank holding companies (BHCs) to examine how the number of commercial-bank subsidiaries affects lending, capital, income, and market measures of efficiency. Consistent with the diversification-discount literature, we find that BHCs with many subsidiaries are less profitable and have lower $q$ ratios than similar BHCs with fewer subsidiaries. These differences are statistically significant even while controlling for size, the number of states in which the bank operates, local market conditions, and the possible endogeneity of the decision to add subsidiaries. We address endogeneity in two ways: first by including BHC-fixed effects, and second by exploiting differ- 
ences in the timing of states' decisions to relax restrictions on intrastate banking to construct instruments for organizational structure. The fixed-effects and instrumental-variables results suggest that the BHC structure is less efficient than more consolidated branch-banking organizations and that the market favors reductions in the number of banking units operated by BHCs. In short, we find that the benefits of internal capital markets may best be realized within firms with fewer independently chartered subunits. These firms enjoy access to internal capital markets without the additional costs of managing a complex, multi-unit organization.

Because we study multi-unit firms in a single industry, commercial banking, our results suggest that at least part of the valuation discount reported in the literature on diversification is the result of organizational structure, not industry or geographic diversification. Even within an industry, and controlling for size and geographic reach, the way the firm organizes its activities into subunits matters to investors. ${ }^{3}$ Studies that fail to control for organizational structure, independent of the distribution of a firm's activities across industries or space, will tend to overstate the effects of diversification on firm value. Our results complement those reported in Sanzhar's (2003) study of "pseudo-conglomerates," firms that report multiple segments in the same 4-digit SIC codes. His sample of multiple-segment, single-industry firms also have lower $q$ ratios than specialized firms. Moreover, single-industry firms that begin reporting multiple segments when required to do so by an exogenous change in accounting rules (FASB rule 131) suffer a loss of value. We interpret Sanzhar's findings as confirmation that investors value not only product and geographic scope, but also organizational structure. Admittedly, our results do not necessarily generalize to industries other than commercial banking. However, by focusing on a clearly and narrowly defined industry, we avoid problems of industry definition that plague multi-industry studies.

Of course, even within an industry firms differ in important ways. All banks take deposits and make loans but banking organizations may hold substantially different loan (asset) portfolios, they may operate in markets with different structural and demographic characteristics, and 
some may engage in nonbank activities. In other words, some "diversity" remains in a singleindustry sample. To control for such differences we include measures of organization size, geographic diversification, characteristics of the loan portfolio and local banking market, the existence of nonbank activity, and other characteristics. To the extent that organizational structure remains a significant determinant of performance or behavior controlling for these characteristics, our analysis allows us to analyze organizational structure independent of industry effects.

The remainder of the paper is organized as follows. Section 2 reviews recent changes in the banking sector and summarizes the most common explanations for bank diversification, consolidation, and organization. Section 3 presents estimates of the effects of holding-company affiliation on lending, capital, and income for individual banks. Section 4 focuses on the banking organization itself and studies the effects of the number of subsidiaries on lending, capital, income, and market value. Section 5 concludes.

\section{Bank Diversification, Consolidation, and Organization}

Since the Bank Holding Company Act of 1956 geographic restrictions on banks have been slowly lifted, enabling banks to expand gradually across state lines. Although barriers to interstate banking were not completely removed until the enactment of the Riegle-Neal Act, regional and interstate pacts enabled BHCs to operate across state lines. ${ }^{4}$ Berger, Kashyap, and Scalise (1995) estimate that by 1994 , a BHC in a typical state had access to nearly 70 percent of U.S. gross domestic banking assets. As banks have expanded, they have also begun to consolidate. Over a third of all banking organizations disappeared during the 1979-94 period, while total banking assets continued to increase (Berger, Kashyap, and Scalise, 1995). Between 1988 and 1997, the numbers of standalone banks and top-level BHCs both fell by almost 30 percent, while the share of total U.S. banking assets held by the top eight banking organizations rose from 22.3 percent to 35.5 percent (Berger, Demsetz, and Strahan, 1999). 
In part, these structural changes are due to technological innovations such as new financial instruments and risk-management techniques, ATMs, phone centers, and on-line banking which permit greater economies of scale (Radecki, Wenninger, and Orlow, 1997). Deregulation, however, is an equally important cause of geographic diversification and consolidation. Prior geographic restrictions on competition may have allowed inefficient banks to survive, and the gradual removal of these restrictions has transformed the structure of the industry (Jayaratne and Strahan, 1998). Moreover, the Glass-Steagall prohibition on combining commercial and investment banking have slowly been lifted. In 1987 the Federal Reserve Board began permitting BHCs to engage in limited nonbank activities through "Section 20" affiliates. Section 20 activities were originally limited to five percent of a subsidiary's total revenue, but the limit was raised to ten percent in 1989 and 25 percent in 1996. The process continued with the Financial Modernization Act of 1999 (the Gramm-Leach-Bliley Act), which allows banks, securities firms, and insurance companies to combine into partially consolidated financial services firms.

The banking literature offers a variety of explanations for expansion and consolidation. Product and geographic diversification allows banks to reduce firm-specific risk by holding a greater variety of assets and offering a greater variety of services (Saunders, Strock, and Travlos, 1990). Of course, shareholders of publicly traded banks can reduce their risk by holding a diversified portfolio of non-diversified banks, gaining the risk-reducing advantages of diversification without incurring the costs of managing a large organization. For this reason most efficiency explanations for product diversification emphasize economics of scope. In financial services, "internal" or cost economies of scope may come from excess capacity in computer and telecommunications equipment that can be used for a variety of products, or from customer information (credit histories, ratings, and the like) that can be used jointly to produce multiple outputs (Clark, 1988, Mester, 1987). "External" or revenue economies of scope exist if there are benefits to the consumer of "one-stop shopping" for various financial services (Berger, Humphrey, and Pulley, 1996). Scope economies, however, need not be realized within a single bank or even within a single BHC. The cost savings from joint production and marketing, for example, could be 
achieved by two separate firms contracting to share facilities, customer data, and marketing information. The consumer benefits of one-stop shopping for bank, insurance, and securities transactions can also be realized by contractual agreements among the various providers. Whether firms will integrate thus depends mainly on the costs and benefits of contracting, not on the underlying production technology.

What about the internal structure of the banking organization? Clearly, large, diversified organizations have potential advantages from exploiting internal capital markets. ${ }^{5}$ However, increased size, scope, and complexity can bring additional overhead costs, agency problems, and inefficient cross-subsidization. It is important to know, therefore, in what form the potential benefits of product and geographic diversification are best exploited. Are economies of scale and scope best realized within a small, narrowly diversified holding company, or within a larger, more widely diversified organization? Moreover, can access to internal capital markets be effectively coordinated by banks within a BHC, or is there a further advantage to consolidating activities within a single bank? Hughes, Lang, Mester, and Moon (1999) provide some evidence on these questions by studying the branch structure of a sample of BHCs in 1994. They find that BHCs with a less complex branch structure, under certain circumstances, are more efficient and more highly valued than other BHCs. We focus instead on the organizational structure of the banking company, asking if internal-capital-market advantages are strongest within banking organizations with multiple independently chartered subsidiaries, or within similarly sized and positioned banks with fewer subsidiaries.

\section{Effects of Holding-Company Affiliation on Bank Lending, Capital, and Income}

We begin by estimating the effects of holding-company affiliation on lending, capital, and income for a panel of U.S. commercial banks. Our sample includes all banks for which data were available from the quarterly Statements of Income and Condition (Call Reports or Y-9C reports) for the years 1990 to 1994 . Table 1 provides descriptive statistics for the panel. As seen in the table, 17,573 of 57,077 , or about 30 percent, of the bank observations are affiliated with multi- 
bank BHCs. Banks affiliated with MBHCs are substantially larger than independent banks, averaging \$796 million in assets, compared to \$101 million for the unaffiliated banks. Table 1 also reports the average total assets of the "banking organization," defined as the BHC for affiliated banks and the bank itself for standalone banks. Average banking organization size for BHCs is nearly two orders of magnitude greater than average size for unaffiliated banks, underlining the substantial variety among banking organizations.

[Table 1 about here]

Table 1 also reports univariate tests of differences in lending, capital, income, characteristics of the loan portfolio, and location for affiliated and unaffiliated banks. Lending is measured by the loans-to-assets ratio (total loans divided by total assets). Capital is measured by the capitalasset ratio (total capital divided by total assets). ROA (return on assets) is defined as net income divided by total assets. As seen in the table, banks affiliated with MBHC have a higher average loans-to-assets ratio and a lower capital-asset ratio than independent banks (differences between means and medians are significant at the 1 percent levels). Because loans represent a bank's primary income-earning asset, banks seek to maximize their lending while holding the minimum capital reserves necessary to maintain adequate liquidity. Affiliated banks also report higher ROA (significant at the 1 percent level). These findings suggest that affiliation with a multibank BHC offers considerable advantages, allowing member banks to do more lending while holding less capital, and earning higher accounting returns.

These univariate tests do not control for other differences between MBHC subsidiaries and independent banks, however. For instance, Table 1 reveals that independent banks are more likely than affiliated banks to make agricultural loans and less likely to be headquartered in a metropolitan statistical area (MSA), suggesting that independent banks serve a different clientele, on average, than that served by affiliated banks. To control for these differences we next run a set of regressions of lending, capital, and profitability (measured as before) on a dummy variable indicating MBHC affiliation and control variables for bank size, banking organization size, and char- 
acteristics of the bank's local market. Bank size is measured by the log of total bank assets, and banking organization size is measured by the log of total assets of the overall banking organization. To control for variation in local-market conditions such as lending opportunities, lending risk, and market structure we include measures of local-market population, per-capita income, and bank concentration, and an indicator for MSA markets. ${ }^{6}$ Each of these is constructed as a deposit-weighted average over all local markets served by each bank (MSAs or non-MSA counties). Concentration is measured using a deposit-Herfindahl computed from the FDIC Summary of Deposits reports. To further control for heterogeneity within the parent banking organization we include a dummy for banks affiliated with parent organizations that include nonbank subsidiaries. $^{7}$ All regressions include year-fixed effects.

Results are reported in Table 2. Panel A report results from pooled OLS regressions, while Panel B report results of panel regressions with bank-fixed effects. The fixed-effects model controls for unobserved bank-specific characteristics, simulating the within-bank effects of joining or leaving a multibank BHC. (The nonbank subsidiary indicator is omitted from the fixed-effects regressions.)

[Table 2 about here]

In both the OLS and fixed-effects regressions we find that banks affiliated with MBHCs do more lending, and hold less capital, than unaffiliated banks, controlling for bank and bank organization size, local market conditions, and characteristics of the bank's loan portfolio. (All differences are significant at the 1 percent level.) The income results are ambiguous, however; the sign on the income variable is positive in the OLS regressions but negative once bank-fixed effects are added. When a bank becomes affiliated with a multibank BHC, then, its lending increases and its capital decreases, but its income also decreases. A possible explanation for the income result is that MBHCs during our sample period were acquiring banks with above-average profitability, resulting in a positive correlation between MBHC affiliation and profitability in the OLS model. However, prior studies of bank acquisitions find no relationship between a bank's 
profitability and the probability that it will be acquired (Hadlock, Houston, and Ryngaert, 1999). Another possibility is that because our panel covers only five years, the observed within-bank changes in profitability are short-term transitional effects. ${ }^{8}$

These results are consistent with existing literature on the benefits and costs of bank internal capital markets. Houston, James, and Marcus (1997) show that MBHCs use internal capital markets to distribute both capital and liquidity to bank subsidiaries. Analyzing the investment-cash flow relationship as in Fazzari, Hubbard, and Petersen (1988), they find that loan growth at MBHC subsidiaries is more sensitive to the holding company's cash flow and capital position than to the subsidiary's own cash flow and capital, and that bank loan growth is negatively related to loan growth among the other subsidiaries in the holding company. Moreover, standalone banks are more dependent on their own internally generated funds than are holding-company affiliates (Houston and James, 1998). This is particularly true among smaller banks when tight monetary policy restricts the aggregate supply of loanable funds (Campello, 2002).

An alternative approach is to use a version of the excess-value measure introduced by Lang and Stulz (1994) for assessing industrial conglomerates. Klein and Saidenberg (2000) compare a sample of MBHCs to benchmark portfolios composed of shares of single banks, weighted to correspond to each MBHC's distribution of activities across size and state. They find that MBHCs hold less capital and do more lending, on average, than their pure-play benchmarks, suggesting that internal capital markets provide net benefits. Moreover, inferences about the effects of bank internal capital markets can be drawn from studies of bank mergers. Berger, and Humphrey (1997) and Berger, Saunders, Scalise, and Udell (1998) find that banks tend to increase their lending and decrease their capital following a merger. The bank internal capital markets literature suggests that this may be because the bank now has access to funds taken from within the larger, merged entity. ${ }^{9}$

A final issue concerns the potential endogeneity of the decision to incorporate a particular bank into a multibank BHC. The fixed-effects model reported in Panel B of Table 2 controls for 
unobserved bank-specific characteristics that are constant throughout our sample period, but not for events occurring during the sample period that cause banks to become part of MBHCs while simultaneously increasing their lending, decreasing their capital, or affecting their profitability. To address this type of bias we estimate an endogenous self-selection model based on Heckman's (1979) two-stage procedure. In the first stage we estimate the likelihood that a bank will be an MBHC subsidiary based on current and lagged values of size, lending, capital, and profitability; local-market conditions as defined earlier, and an instrument based on Campa and Kedia (2002) that captures the geographic clustering of bank organization. Campa and Kedia estimate a diversification discount for industrial firms with a Heckman model that instruments for a given firm's decision to diversify using the proportion of firms in that firm's industry that are already diversified. The rationale is that the decision to diversify into a particular industry depends on industry-specific factors that do not affect a given firm's performance relative to its industry peers. We proceed, similarly, with the assumption that bank holding companies are systematically attracted to banks in particular locations, using the percentage of banks in a given state that are already members of bank holding companies as a proxy for the attractiveness of that state to BHCs. Our instrument is computed for each bank-year as the percentage of banks in the given bank's state, in the same year, that are MBHC subsidiaries. The second-stage outcome regressions model lending, capital, and profitability as functions of the same independent variables used in Table 2 and include $\lambda$, the inverse Mills ratio or nonselection hazard derived from the first-stage probit regression, as a correction for the endogeneity of the MBHC selection decision. They also include state-level indicators. Because our measures of bank performance (profitability, lending, and capital) are measured relative to other banks in the same state, these variables are not correlated with the instrument.

Results from the first-stage probit regression are reported in Panel A of Table 3. The results show that current values of size, lending, capital, and profitability are statistically significant predictors of MBHC affiliation; holding-company subsidiaries do more lending, hold less capital, and are more profitable than independent banks (size is not statistically significant). Lagged val- 
ues of capital and profitability are also statistically significant predictors, with the same signs as their current values. The coefficient on lagged lending, however, is negative and statistically significant, suggesting that banks with historically high levels of lending are not systematically targeted for MBHC membership. The coefficient on the instrument is positive and statistically significant, indicating that $\mathrm{MBHC}$ affiliation is strongly clustered by state.

[Table 3 about here]

The outcome regressions are reported in Panel B of Table 3. The lending and capital results are similar to those reported in Table 2. Even controlling for the endogeneity of the decision to incorporate a particular bank into a multibank BHC, member banks do more lending and hold less capital than unaffiliated banks (controlling as well for size, local-market conditions, and characteristics of the bank's loan portfolio). The sign on MBHC affiliation is negative but not statistically significant in the income regression. As in the OLS model reported in Table 2, affiliated banks earn enough income to compensate for the administrative costs of membership in a larger organization. (Like the OLS model, however, the self-selection model does not include bank-fixed effects, and the serial correlation of within-bank error terms biases the coefficient estimates upward, so the income results remain ambiguous.) The nonselection hazard parameter, $\lambda$, is statistically significant in all three regressions, indicating the presence of endogenous selfselection. Even once this endogeneity is taken into account, however, the positive relationship between MBHC affiliation and lending, and the negative relationship between MBHC affiliation and capital, remain, suggesting that the results reported in Table 2 are robust to various forms of endogeneity bias.

\section{Effects of Organizational Form on Lending, Capital, Income, and Market Value}

The evidence presented above shows that banks affiliated with MBHCs tend do more lending and hold less capital than independent banks, suggesting that access to internal capital markets has advantages for member banks. However, a BHC can have an internal capital market with on- 
ly two member banks. Why, then, should we observe MBHCs with as many as 86 independently chartered subsidiaries (the maximum in our sample)? In other words, for a banking organization of given size, how are internal-capital-market advantages best exploited? The practitioner literature suggests that the consolidation of bank charters can improve performance by eliminating operational redundancies while providing consistent product offerings across states. ${ }^{10}$ Yet we know little about the effects of organizational form on the performance of BHCs (or, for that matter, industrial firms).

\subsection{Sample and Data}

To address these questions we construct a new sample at the level of the parent holding company rather than the individual bank. We assemble a panel of publicly traded BHCs to see how the number of commercial bank charters affects lending, capital, income, and market value. (Because we are interested in market measures of performance, we restrict the sample to publicly traded holding companies.) We begin by identifying more than 350 publicly traded BHCs by comparing institutions' names in both 1985 and 1995 regulatory reports to names on the Center for Research in Security Prices (CRSP) tapes. To minimize survivorship bias in the final sample, we build the data set by tracking the 1986 and 1995 subsamples throughout the intervening years. As above, our analysis draws on data from the 1990-94 period. We limit our analysis to those BHCs for which we could find an unambiguous match between the CRSP tapes and the consolidated financial statements (the Y-9C reports) describing BHC characteristics. This results in a sample of $367 \mathrm{BHCs}$, or 1,321 BHC observations over the five-year period.

For each BHC observation, we compute three ratios: loans to assets, capital to assets, and return on assets. We construct balance-sheet and income ratios for each BHC as asset-weighted averages of the ratios for its commercial bank subsidiaries, using Call Report data. Using stockprice data from publicly traded BHCs, we compute Tobin's $q$, which we define as the ratio of the market value of capital to the replacement cost of capital. The future profitability of the BHCprofitability stemming from efficiency, market power, or lending relationships-will be reflected 
in the numerator but not the denominator. Thus $q$ captures the present value of the $\mathrm{BHC}$ in a way that permits comparison across banks. Replacement cost is difficult to measure, and it is particularly problematic at banks. We use the book value of tangible equity as a proxy for replacement cost, and measure firm value as the ratio of the market value of equity divided by the book value of tangible equity. Like all observable proxies for "true" $q$, ours is imperfect. However, banks issue relatively little long-term debt, so the book value of tangible equity may be a better approximation of the replacement cost of capital than the proxies used to compute $q$ for industrial firms (Boyd and Runkle, 1993). ${ }^{11}$

Table 4 provides descriptive statistics for the sample of publicly traded BHCs. The first column summarizes the entire sample, and the subsequent columns separate the sample into groups based on the number of bank subsidiaries. For the full sample, the average BHC has slightly more than five commercial bank charters and operates in about 2 states. The banking organizations average $\$ 8.3$ billion in assets, ranging from $\$ 102$ million to $\$ 250$ billion.

\section{[Table 4 about here]}

Comparing values across rows, there is little systematic variation in lending or capital ratios among BHCs with different numbers of bank subsidiaries. Profitability is systematically increasing in the number of subsidiaries, but the variation in $q$ is nonlinear. Average $q$ for the full sample is 1.27 (median 1.24). BHCs with 30 or more subsidiaries have the highest average $q$ (1.60, median 1.62), while BHCs with 20-29 subsidiaries have the lowest average $q(1.17$, median 1.28).

Inspection of the mean and median values for the numbers of banks and states in each category reveals that the number of bank subsidiaries is not simply a proxy for geographic diversification. BHCs with 2-9 subsidiaries average 4.1 banks but operate in only 1.9 states. BHCs with 10-19 subsidiaries operate in four states, on average, and even BHCs with 30 or more subsidiaries are active in only about six states. Still, to be sure we are separating the effects of organiza- 
tional complexity and geographic diversification we include the number of states as a control variable in most of the regressions reported below.

The table also reveals that larger BHCs do not necessarily have larger bank subsidiaries. The median value of BHC assets per bank subsidiary is generally decreasing in the number of subsidiaries, though it rises again for the largest BHCs (30 or more bank subsidiaries). This is consistent with the idea that organizational complexity is costly to manage; the more subsidiaries a BHC controls, the smaller the subsidiaries must be, on average, to make such control viable. ${ }^{12}$

\subsection{Basic Results}

We begin with panel-data regressions of lending, capital, income, and market value on the number of independently chartered subsidiaries (in logs), the size of the holding company (log of total assets), an index of state-level economic conditions, and a dummy variable for BHCs with a nonbank subsidiary. The index of state-level economic conditions is defined as an assetweighted average of the state-level income growth rates for all states in which the BHC operates. We include fixed effects to control for unobserved heterogeneity. The fixed-effects model also allows us to simulate balance-sheet and market-value reactions to changes in the number of independently chartered subsidiaries within a single banking organization. We also include yearfixed effects.

To control for geographic diversification, we run a parallel set of regressions that also include the log of the number of states in which the BHC has member banks. As described above, many multi-state BHCs have more than one subsidiary per state; still, the correlation between the number of subsidiaries and the number of states is fairly high $(0.662$, significant at the 1 percent level). Multicollinearity is thus a concern in the models with both regressors.

Results of the five sets of panel regressions are presented in Table 5. The coefficients on the number of bank subsidiaries in the lending regressions are positive (significant at the 5 percent level in the regression without the number of states). Its coefficients in the capital regressions are 
negative but not significant. The coefficients in both sets of income regressions are negative and significant in all but one specification. Finally, the coefficient in the set of $q$ regression is negative and significant (at the 1 percent level without the number-of-states control, and the 10 percent level with it). The market appears to be imposing a diversification discount-or, more precisely, a number-of-charters discount — on large, highly diversified BHCs. This is true even when controlling for the number of states in which the BHC operates, indicating that the market is evaluating organizational structure, not simply geographic diversification. Moreover, because the model includes BHC-fixed effects, the results support the claim that the market favors a reduction in the number of independently chartered subsidiaries. Similarly, accounting income improves when the number of subsidiaries falls, holding constant bank size and local economic conditions.

[Table 5 about here]

As in Campa and Kedia (2002), the use of fixed effects shows that the negative correlation between $q$ and the number of charters is not driven by unobserved heterogeneity. In other words, it is not the case that hidden BHC-specific characteristics cause particular BHCs to be both diversified and undervalued, leading to the mistaken conclusion that organizational complexity reduces $q$. The negative relationship between bank charters and $q$ holds even within a given BHC.

The signs on our significant coefficients are economically significant as well. In the first $q$ regression, for example, the coefficient on the number of subsidiaries (measured in logs) is -0.092 . Evaluated at the mean, a one-standard-deviation reduction in the log of the number of subsidiaries (equivalent to a 2.8-unit reduction in the number of subsidiaries) increases $q$ by about ten percent. Stated differently, if a BHC has five subsidiaries (the mean in our sample is 5.39), reducing the number of subsidiaries to four increases $q$ by 0.02 . This is a smaller "diversification discount" than that found by Lang and Stulz (1994), Berger and Ofek (1995), and other authors. However, those studies measure the effects of two factors: changes in organizational 
structure and changes in industry diversification. Because we look within a single industry, our results pick up only the effects of changes in organizational structure. Not surprisingly, we find a smaller discount than that reported in the diversification literature.

More precisely, Table 5 indicates that an increase in bank charters from 1 to 2 decreases $q$ by 0.06, controlling for size and geographic diversification. By comparison, in Lang and Stulz's (1994) sample, an increase in segments from 1 to 2 reduces $q$ by 0.10 to 0.50 (controlling for size and industry). To the extent that a multibank BHC has the same organizational structure as a multi-segment conglomerate, anywhere from twelve to sixty percent of Lang and Stulz's discount may be an organizational-structure discount rather than a diversification discount. The comparison is not exact, however, because Lang and Stulz's estimates are based on crosssectional regressions, not within-firm estimates. Campa and Kedia (2002) apply a fixed-effects model similar to ours to a panel of manufacturing firms; in their model, an increase in segments from one to two or more reduces industry-adjusted $q$ by 0.04 to 0.14 , depending on whether only diversifying or only refocusing firms are included and whether segment weights are based on sales or assets. These estimates are closer to, though still generally higher than, our estimates of the effects of organizational consolidation within a single industry. Again, our analysis suggests that part of Campa and Kedia's observed diversification discount may be due to organizational structure, not industry effects. ${ }^{13}$

While our sample firms are from the same industry, there is still considerable variation among them. The largest BHCs, those with the greatest numbers of subsidiaries, and those located in a major financial center presumably oversee a greater range of activities than smaller, less complex BHCs located elsewhere. To further distinguish diversification from organizational structure we re-estimated the same models using various subsamples containing more homogenous sets of BHCs - dropping the largest and smallest quartiles by total assets, those with 25 or more bank subsidiaries, money-center BHCs (those headquartered in New York, Charlotte, and San Francisco), and BHCs with nonbank subsidiaries. ${ }^{14}$ In each case, the results were nearly 
identical to those presented in Table 5, suggesting that the results are not driven by crosssectional heterogeneity.

The descriptive statistics presented in Table 4 suggest that the effects of organizational complexity may be nonlinear. For this reason, we re-estimate the regressions described above using dummy variables for BHCs with 2 to 4,5 to 9,10 to 14,15 to 19,29 to 24,25 to 29 , and 30 or more bank charters (leaving one-bank BHCs as the excluded category). We include the same control variables as in the regressions reported in Table 5. As in Lang and Stulz (1994), the coefficients on the dummy variables represent the marginal effects on our dependent variables of adding those additional charters. The results, presented in Table 6 , are generally consistent with, though weaker than, the results presented in Table 5. The coefficients on the dummy variables in the lending regressions are positive (statistically significant in only two regressions), though the coefficients on dummy variables in the capital regressions are not statistically significant. The coefficients on the dummy variables in the income regressions are negative and statistically significant in all but two cases. In the $q$ regressions, the coefficients on the dummy variables are negative, and statistically significant in all but one case. This confirms what is reported in Table 4, namely that the effect of organizational complexity on firm value is nonlinear, even controlling for size, geographic diversification, local-market conditions, and other firm-specific characteristics, with the strongest effect when the number of BHC subsidiaries is very large.

[Table 6 about here]

\subsection{Endogeneity}

As is widely recognized in the diversification-discount literature, the results reported in Tables 4 and 5 could be driven by endogeneity between organizational form and $q$. Diversification (as we interpret it here, an increase in organizational complexity) could be a response to poor

performance, not a cause. For example, if low- $q$ BHCs subsequently add bank subsidiaries, trying to improve their performance, then regressions such as those presented above will tend to 
find a negative relationship between bank charters and $q$, even if this relationship has nothing to do with the effects of multiple charters per se. The use of fixed effects mitigates this problem between BHCs, but does not address the possibility of within-BHC reverse causation. ${ }^{15}$

While this is clearly a problem in studies of industrial diversification, we do not think it is likely to be significant in our case. Historically, poorly performing BHCs have retrenched, not expanded geographically by adding additional bank subsidiaries (Jayaratne and Strahan, 1998). Nonetheless, to control for the potential endogeneity between our dependent variables and organizational structure we re-estimate the same regressions, this time using exogenous instruments for the number of bank charters. To construct the instruments we take advantage of the fact that restrictions on intrastate branching and interstate banking were relaxed only gradually, in some states more quickly than in others (Kroszner and Strahan, 1999). BHCs located in states that permit statewide branching, for example, will tend to have fewer independently chartered bank subsidiaries than BHCs located in states that restrict intrastate branching. Because the variation in state banking regulations is presumably unrelated to the variation in our dependent variables, we can use state banking regulations to construct instruments for organizational complexity.

Our data on the evolution of state banking restrictions are taken from Berger, Kashyap, and Scalise (1995). They distinguish among five regulatory regimes: unit-banking states, limitedbranching states, states permitting statewide branching, states permitting statewide BHC expansion, and states permitting interstate BHC expansion. During the first year of our sample, 1990, only two states, Colorado and Missouri, were unit-banking states, meaning they allowed only one full-service office per bank. By 1992 all 50 states allowed at least some intrastate branching. About half the states allowed statewide branching in 1990, increasing to three-fourths by 1994 . All 50 states allowed at least some intrastate BHC expansion prior to 1990, and by 199470 percent placed no restrictions on intrastate BHC expansion. All but Hawaii allowed at least some interstate BHC expansion by 1994. Of these changes in regulation, the greatest variation during 
our sample period is the rate at which states permitted statewide branching, so we use this variable to construct our instruments.

Table 7 presents the second-stage instrumental-variables results. The instrument for the number of bank subsidiaries is the percentage of BHC assets in states permitting statewide branching during the pervious year. The instrument performs well in the first-stage regression; it is negative, as expected, and statistically significant at the 5 percent level, meaning that prior restrictions on intra-state branching encourage the formation of BHCs with larger numbers of subsidiaries. The second-stage results are generally consistent with, though weaker than, those presented in Table 5. The coefficients on the number of bank subsidiaries are negative and significant in the capital regressions and in the $q$ regressions. (They are generally negative in the income regressions, though not statistically significant, and not significant in the lending regressions.) The coefficients in the $q$ regressions are larger in absolute value than the corresponding coefficients in the regressions without the instrumental variables. ${ }^{16}$

\section{[Table 7 about here]}

Because the equations behind the analysis in Table 7 are exactly identified (one endogenous variable and one excluded instrument in the second-stage regression) we cannot run specification tests for instrument validity. To check the validity of the statewide-branching instrument we add two additional instruments based on population and geography and test the overidentifying restrictions on the excluded instruments (Sargan, 1958). The first additional instrument is the population, from the 1990 Census, in the BHC's home state. The larger the population, the more customers can be served without crossing state lines (requiring the establishment of a new bank subsidiary). The second additional instrument is the population density (population divided by land square miles) in the BHC's home state, again taken from the 1990 Census. The greater the population density, the more customers can be served without setting up additional in-state branches. When these additional instruments are included the $p$-values from the overidentification tests are within conventional bounds, supporting the exogeneity of the instruments. How- 
ever, neither the population nor density variable is statistically significant in the first-stage regression and once these additional instruments are included the regressions fail the Stock and Yogo (2005) test for weak instruments (which is passed in the original specification). In any case, including the additional instruments has virtually no effect on the point estimates or significance levels of the second-stage regressions reported in Table 7.

Combined with the results described in previous sections the instrumental-variables results support an explanation for bank structure and performance based on regulatory constraints. Prior to Riegle-Neal, restrictions on intrastate branching and interstate banking prevented banking organizations from expanding geographically without establishing new subsidiaries. These constraints forced banks to adopt inefficient organizational structures that would not otherwise have been chosen. As these constraints were lifted, banking organizations, not surprisingly, began to consolidate their operations to improve efficiency. The higher valuations reported for more consolidated organizations suggest that investors expect such efficiency gains to be substantial and ongoing.

\subsection{The Costs of Diversity}

As discussed above, the literature on industrial diversification offers several reasons why multiple-segment firms might be discounted relative to single-segment firms. Several explanations emphasize the intra-firm competition for corporate resources. Scharfstein and Stein (2000) show how firm value can be lost through divisional rent-seeking and influence activities. Rajan, Servaes, and Zingales (2000) argue that the greater the diversity of divisional resources and investment opportunities, the more likely that corporate resources will be shifted in the wrong direction, i.e., from divisions with more resources and more desirable investment opportunities to those with fewer resources and less desirable investment opportunities. In their model, the corporate office allocates resources to projects but cannot commit to the ex post division of the surplus. Managers of divisions with more resources or better investment opportunities than other divisions may thus favor "defensive" investments that offer lower returns, but allow them to 
keep more of the surplus. Firm-level investment will then be more efficient the more similar are divisional resources and opportunities. Using a panel of diversified firms the 1980s and early 1990s, they show that firm value is negatively related to the within-firm variation in divisional investment opportunities (proxied by size-weighted industry $q$ ).

To see if the costs of organizational complexity are related to intra-firm diversity, we run additional regressions of firm value on the number of bank charters and the control variables described above, along with three measures of intra-firm diversity: the within-BHC standard deviations of bank subsidiary size, bank subsidiary capital-to-assets ratio, and bank subsidiary lending. Size and capital ratio can be interpreted as proxies for bargaining power, and lending as a proxy for growth opportunities. These regressions use only the 819 multiple-bank BHCs in the sample. We run two sets of panel regressions, the first with BHC-specific fixed effects and the second with fixed effects and instruments for the number of bank subsidiaries. As above, we use the percentage of $\mathrm{BHC}$ assets in states permitting statewide branching in the previous year as the instruments.

Results are presented in Table 8. As seen in the table, the results are consistent with the costs-of-diversity hypothesis, though not strongly so. The coefficient on the standard deviation of bank size is negative in all specifications, though statistically significant in only one of the four regressions. The standard deviation of bank capital is not statistically significant in any specification. The coefficient on the standard deviation of bank lending is negative and statistically significant in the first two regressions. In short, we find some evidence for a negative relationship between firm value and the variations in bank subsidiary size and bank subsidiary lending. This suggests that the cost of managing a complex organization is increasing in subsidiary heterogeneity, even controlling for the number of subunits, the number of states in which the BHC operates, the size of the overall organization, and the possible endogeneity of the number of BHC subsidiaries.

[Table 8 about here] 
While the analogy with Rajan, Servaes, and Zingales (2000) is not exact - their model is driven by division managers' choices among types of investments, some more easily appropriated than others, while the bank loans we study represent a more homogeneous class of investmentthe institution is similar. Frictions between bank subsidiary managers and the corporate office, and the resulting misallocations of capital and liquidity within the $\mathrm{MBHC}$, are increasing in subsidiary heterogeneity, controlling for the number of subsidiaries. Bank subsidiaries with little bargaining power over the distribution of investment surpluses will be less likely to pursue all profitable lending opportunities than would be the case if all subsidiaries had similar amounts of bargaining power.

As before, because we study firms from a single industry, commercial banking, and we control for geographic diversification, the results in Table 8 can be interpreted as reflecting the costs of organizational complexity, not the costs of industry or geographic diversification. Of course, as discussed above, BHCs do not produce identical "products" (loans, intermediation services, and so on), so we cannot ignore product diversification entirely. Still, the cross-firm heterogeneity found in samples of banking institutions is substantially lower than that found in samples of industrial conglomerates. Moreoever, as noted above, our analysis controls as much as possible for other firm characteristics (such as local market conditions) that affect firm behavior and performance. For this reason, we think our results do capture an important kind of organizational complexity that is different from industrial diversification.

\subsection{Summary and Implications}

The analysis presented here shows that the value of a bank is sensitive to organizational form, controlling for organization size, the states in which the organization operates, localmarket conditions, unobservable bank-specific characteristics, and the possible endogeneity of the decision to diversify. This suggests that the average diversified MBHC could improve its performance by consolidating, operating in the same states and on the same scale but with fewer independently chartered subsidiaries. This appears to have happened following the Riegle-Neal 
Act. The number of U.S. banks and thrifts fell from about 12,500 in 1994 to about 9,000 in 2003, while the number of bank branches rose steadily, increasing by nearly 9 percent (Hirtle and Metli, 2004). ${ }^{17}$ During this same period, the number of banking organizations with branches in more than state nearly doubled (Hirtle and Metli, 2004). Between 1995 and 1999 the average share of local bank deposits held by interstate branches of out-of-state BHCs rose from 0.01 to 0.22 , while the average share of local bank deposits held by in-state branches of subsidiaries of out-of-state BHCs fell from 0.31 to 0.20 (Whalen, 2000, Table 4).

These data suggest that multistate banking firms are increasingly using interstate branches, rather than separate out-of-state bank subsidiaries, to reach customers in other states. Indeed, tracing forward our own sample of BHCs past 1994, we find that those with the largest numbers of subsidiaries have consolidated sharply. Norwest, for example, went from 73 subsidiaries in 1994 to 44 in 1995, eventually falling to 37 by 1998 when it merged with Wells-Fargo, while its assets more than doubled during this period. Banc One had 75 subsidiaries in 1994, 63 in 1995, 43 in 1996, and 15 in 1997; by 2002 it was down to nine. Its assets increased three-fold during this period. Suntrust went from 30 subsidiaries in 1994 to 27 in 1999 even as its assets grew by 125 percent.

Our results imply that this consolidation is driven by efficiency considerations. Consolidation may also be interpreted as a continuation of the selection process in which better-managed, more efficient banks expand at the expense of inefficient ones. This process, long retarded by prohibitions on interstate banking and intrastate branching, led to improved bank performance in the 1970s and 1980s. Jayaratne and Strahan (1998) show that average bank efficiency improved substantially once restrictions on intrastate branching (and, to a lesser extent, interstate banking) were removed during the 1970s and 1980s.

Another possible interpretation of our results is that prior to Riegle-Neal, low- $q$ BHCs with many subsidiaries began positioning themselves for the anticipated relaxation of interstate branching restrictions in 1994. Our number-of-subsidiaries discount is thus a "price" paid by 
these banks for strategic (location) advantages. This interpretation suffers from two problems, however. First, the number-of-charters discount remains even when controlling for the number of states in which the BHC operates, so at least part of the discount cannot be interpreted as a price for operating in more states. Second, to the extent that the changes brought about by the Riegle-Neal Act were anticipated, the effects of this kind of strategic positioning should already be incorporated in $q$. For these reasons we are satisfied that our discount reflects organizational structure, not simply expectations of future regulatory changes.

\section{Conclusion}

Our analysis provides evidence on the relationship between organizational structure and performance at BHCs. The first part demonstrates advantages of access to internal capital markets: banks affiliated with an MBHC do more lending, and hold less capital, than unaffiliated banks. This suggests that these organizations benefit from the intra-firm allocation of resources. The second part shows that the structure of the internal capital market is important: BHCs with many subsidiaries have lower profits and lower market valuations than similar BHCs with fewer subsidiaries, suggesting that multi-unit structure are less efficient than more consolidated ones. The valuation discount is statistically significant even while controlling for size, geographic scope, and local economic conditions. In other words, the benefits of internal capital markets are better realized within firms with fewer independently chartered subunits. These firms enjoy access to internal capital markets without the additional costs of managing a diverse, multi-unit organization. Looking within firms, we find that market value rises as the number of banking units operated by BHCs falls, even controlling for the possible endogeneity of the decision to reduce the number of subsidiaries. This helps explain why banks are consolidating their operations as interstate branching restrictions are lifted.

More generally, our results show that market valuations reflect not only the firm's distribution of activities across industries or regions, but also how the firm's activities are organized into subunits, even within an industry or market segment. Unfortunately, organizational structure has 
been downplayed in the empirical literature on corporate diversification. Most recent studiesours included - use crude, but easily measured, proxies for organizational form, such as the number of business segments or subsidiaries, the average variation in subsidiary characteristics, and so on. An older literature, inspired by the "M-form hypothesis" of Chandler (1962) and Williamson (1975), uses qualitative classifications of organizational structure based on interviews, case studies, and other company documents (Armour and Teece, 1978; Harris, 1983; Cable and Dirrheimer, 1983; Cable and Yasuki, 1985; Hill, 1985). Unfortunately, these classifications are available only for small samples of firms, and prior studies have not produced consistent results. Another possibility is to distinguish between functionally organized firms and firms organized by product line or geographic area based on the titles of senior executives (Agrawal, Knoeber, and Tsoulouhas, 2003). As the cost of obtaining detailed information on organizational structure falls - at least for publicly traded U.S. companies whose public filings are available on the SEC's EDGAR system ${ }^{18}$ - we look forward to a new body of empirical literature that takes organizational form more seriously. 


\section{References}

Adams, Renée B., and Hamid Mehran. 2002. "Board Structure and Banking Firm Performance." Working paper, Federal Reserve Bank of New York, 2002.

Akhavein, Jalal D., Allen N. Berger, and David B. Humphrey. 1997. "The Effects of Bank Megamergers on Efficiency and Prices: Evidence from the Profit Function." Review of Industrial Organization 11: 95-139.

Alchian, Armen A. 1969. "Corporate Management and Property Rights." In Henry Manne, ed., Economic Policy and the Regulation of Corporate Securities. Washington, D.C.: American Enterprise Institute, pp. 337-60.

Armour, Henry O., and David J. Teece. 1978. "Organizational Structure and Economic Performance: A Test of the Multidivisional Hypothesis." Bell Journal of Economics 9: 106-122.

Berger, Allen N., Rebecca S. Demsetz, and Philip E. Strahan. 1999. "The Consolidation of the Financial Services Industry: Causes, Consequences, and Implications for the Future.” Journal of Banking and Finance 23 (February): 135-94.

Berger, Allen N., David B. Humphrey, and Lawrence B. Pulley. 1996. "Do Consumers Pay for One-Stop Banking? Evidence from an Alternative Revenue Function." Journal of Banking and Finance 20 (November): $1601-21$.

Berger, Allen N., Anil K. Kashyap, and Joseph M. Scalise. 1995. "The Transformation of the U.S. Banking Industry: What a Long, Strange Trip It's Been.” Brookings Papers on Economic Activity: 55-201.

Berger, Allen N., Anthony Saunders, Joseph M. Scalise, and Gregory S. Udell. 1998. "The Effects of Bank Mergers and Acquisitions on Small Business Lending." Mimeo, Board of Governors of the Federal Reserve Board.

Berger, Philip G., and Eli Ofek. 1995. “Diversification's Effect on Firm Value.” Journal of Financial Economics 37 (January): 39-65.

Boyd, John H., and David E. Runkle. 1993. "Size and Performance of Banking Firms: Testing the Predictions of Theory." Journal of Monetary Economics 31 (February): 47-67.

Cable, John, and M. Dirrheimer. 1983. "Hierarchies and Markets: An Empirical Test of the Multidivisional Hypothesis in West Germany." International Journal of Industrial Organization 1: 43-62.

Cable, John, and Hirohiko Yasuki. 1985. "Internal Organization, Business Groups, and Corporate Performance: An Empirical Test of the Multidivisional Hypothesis in Japan." International Journal of Industrial Organization 3: 421-38.

Campa, Jose Manuel, and Simi Kedia. 2002. "Explaining the Diversification Discount." Journal of Finance 57 (August): 1731-62.

Campello, Murillo. 2002. "Internal Capital Markets in Financial Conglomerates: Evidence from Small Bank Responses to Monetary Policy.” Journal of Finance 57 (December): 2773-805. 
Cebenoyan, A. Sinan, and Philip E. Strahan. 2000. "Risk Management, Capital Structure, and Lending at Banks.” Working Paper, Carroll School of Management, Boston College.

Chandler, Alfred D. 1962. Strategy and Structure: Chapters in the History of the American Industrial Enterprise. Cambridge, Mass.: MIT Press.

Chevalier, Judith A. 2000. "Why Do Firms Undertake Diversifying Mergers? An Examination of the Investment Policies of Merging Firms." Working paper, Graduate School of Business, University of Chicago.

Clark, Jeffrey A. 1988. "Economies of Scale and Scope at Depository Financial Institutions: A Review of the Literature." Federal Reserve Bank of Kansas City Economic Review (September-October): 1633.

Demsetz, Rebecca. 2000. "Bank Loan Sales: A New Look at the Motivations for Secondary Market Activity.” Journal of Financial Research 23: 192-222.

Demsetz, Rebecca, Mark R. Saidenberg, and Philip E. Strahan. 1996. "The Disciplinary Role of Franchise Value: Banks with Something to Lose." Federal Reserve Bank of New York Economic Policy Review 2 (October): 1-14.

Demsetz, Rebecca, Mark R. Saidenberg, and Philip A. Strahan. 1998. "Agency Problems and Risk Taking at Banks.” Federal Reserve Bank of New York Staff Report 29.

Diamond, Douglas W. 1984. "Financial Intermediation and Delegated Monitoring." Review of Economic Studies 51: 393-414.

Fazzari, Steven M., R. Glenn Hubbard, and Bruce C. Petersen. 1988. "Financing Constraints and Corporate Investment." Brookings Papers on Economic Activity 1: 141-95.

Froot, Kenneth A., and Jeremy C. Stein. 1998. "Risk Management, Capital Budgeting, and Capital Structure Policy for Financial Institutions: An Integrated Approach.” Journal of Financial Economics 47: $55-82$.

Galloway, T. M., W. B. Lee, and D. M. Roden. 1997. "Banks' Changing Incentives and Opportunities for Risk Taking." Journal of Banking and Finance 21 (April): 509-27.

Graham, John R., Michael Lemmon, and Jack Wolf. 2002. "Does Corporate Diversification Destroy Value?" Journal of Finance 57 (April): 695-720.

Hadlock, Charles, Joel Houston, and Michael Ryngaert. 1999. "The Role of Managerial Incentives in Bank Acquisitions.” Journal of Banking and Finance 23 (February): 221-49.

Harris, Barry C. 1983. Organization: The Effect on Large Corporations. Ann Arbor: University of Michigan Press.

Heckman, James. 1979. "Sample Selection Bias as Specification Error.” Econometrica 47: 153-61. 
Hill, Charles W. L. 1985. "Internal Organization and Enterprise Performance: Some U.K. Evidence." Managerial and Decision Economics 6, no. 4: 210-16.

Hirtle Beverly, and Christopher Metli. 2004. "The Evolution of U.S. Bank Branch Networks: Growth, Consolidation, and Strategy." Federal Reserve Bank of New York Current Issues in Economics and Finance 10: 1-7.

Houston, Joel, Christopher James, and David Marcus. 1997. "Capital Market Frictions and the Role of Internal Capital Markets in Banking.” Journal of Financial Economics 46 (November): 135-64.

Houston, Joel, and Christopher James. 1998. "Do Bank Internal Capital Markets Promote Lending?" Journal of Banking and Finance 22 (August): 899-918.

Hughes, Joseph P., William Lang, Loretta J. Mester, and Choon-Geol Moon. 1999. "The Dollars and Sense of Bank Consolidation.” Journal of Banking and Finance 23 (February): 291-324.

Jayaratne, Jith, and Philip E. Strahan. 1998. "Entry Restrictions, Industry Evolution, and Dynamic Efficiency: Evidence from Commercial Banking." Journal of Law and Economics 41 (April): 239-73.

Kahle, Kathleen M., and Ralph A. Walkling. 1996. "The Impact of Industry Classifications on Financial Research." Journal of Financial and Quantitative Analysis 31, no. 3: 309-35.

Keely, M. 1990. "Deposit Insurance, Risk, and Market Power in Banking." American Economic Review 80 (December): 1183-1200.

Keren, M., and D. Levhari. 1983. "The Internal Organization of the Firm and the Shape of Average Costs.” Bell Journal of Economics (Autumn): 474-88.

Klein, Peter G., and Marc R. Saidenberg. 2000. "Diversification, Organization, and Efficiency: Evidence from Bank Holding Companies.” In Patrick T. Harker and Stavros A. Zenios, eds., Performance of Financial Institutions. Cambridge: Cambridge University Press, pp. 153-73.

Kroszner, Randall S., and Philip E. Strahan. 1999. "What Drives Deregulation? Economics and Politics of the Relaxation of Bank Branching Restrictions." Quarterly Journal of Economics 114 (November): $1437-67$.

Lang, Larry H. P., and René M. Stulz. 1994. “Tobin's Q, Corporate Diversification, and Firm Performance.” Journal of Political Economy 102 (December): 1248-80.

Lien, Lasse B., and Peter G. Klein. 2004. "Using Competition to Measure Relatedness.” Working Paper, Norwegian School of Economics and Management.

Matsusaka, John G., and Vikram Nanda. 2002. "Internal Capital Markets and Corporate Refocusing." Journal of Financial Intermediation 11: 176-211.

Mester, Loretta J. 1987. "Efficient Production of Financial Services: Scale and Scope Economies." Federal Reserve Bank of Philadelphia Business Review (January-February): 15-25. 
Radecki, Lawrence J., John Wenninger, and D. K. Orlow. 1997. "Industry Structure: Electronic Delivery's Potential Effects on Retail Banking.” Journal of Retail Banking Services 19, no. 4: 57-63.

Rajan, Raghuram, Henri Servaes, and Luigi Zingales. 2000. "The Cost of Diversity: The Diversification Discount and Inefficient Investment.” Journal of Finance 55 (February): 35-80.

Sanzhar, Sergei. 2003. "Two Puzzles about the Diversification Discount: SFAS No. 131 and 'PseudoConglomerates."' Working paper, Kenan-Flagler School of Business, University of North Carolina, Chapel Hill.

Sargan, J. Denis. 1958. "The Estimation of Economic Relationships with Instrumental Variables." Econometrica 26, no. 3: 393-415.

Saunders, Anthony, Elizabeth Strock, and Nickolaos G. Travlos. 1990. "Ownership Structure, Deregulation, and Bank Risk Taking.” Journal of Finance 45 (June): 643-54.

Scharfstein, David S., and Jeremy C. Stein. 2000. "The Dark Side of Internal Capital Markets: Divisional Rent-Seeking and Inefficient Investment.” Journal of Finance 55 (December): 2537-64.

Shin, Hyun-Han, and René M. Stulz. 1998. “Are Internal Capital Markets Efficient?” Quarterly Journal of Economics (May): 531-52.

Stein, Jeremy C. 1997. "Internal Capital Markets and the Competition for Corporate Resources." Journal of Finance 52, no. 1 (March): 111-33.

Stock, James H., and Motohiro Yogo. 2005. “Testing for Weak Restrictions in Linear IV Regression.” In Donald W. K. Andrews and James H. Stock, eds., Identification and Inference for Econometric Models: Essays in Honor of Thomas Rothenberg. Cambridge: Cambridge University Press.

Strahan, Philip E., and James P. Weston. 1998. "Small Business Lending and the Changing Structure of the Banking Industry.” Journal of Banking and Finance 22: 821-45.

Villalonga, Belén. 2004. "Does Diversification Cause the Diversification Discount?” Financial Management 33, no. 2 (Summer): 5-27.

Whalen, Gary. 2000. "Interstate Banking, Branching, Organization Size, and Market Rivalry." Office of the Comptroller of the Currency, E\&PA Working Paper 2000-7.

Whited, Toni M. 2001. "Is It Inefficient Investment that Causes the Diversification Discount?" Journal of Finance 56, no. 5 (October): 1667-92.

Williamson, Oliver E. 1975. Markets and Hierarchies: Analysis and Antitrust Implications. New York: Free Press. 


\section{Table 1: Bank Summary Statistics}

Summary statistics for sample of U.S. commercial banks, 1990 to 1994 . The sample includes all bank observations for which data are available from quarterly Statements of Income and Condition (Call Reports or Y-9C reports). Total banking organization assets equals total bank assets for independent banks and subsidiaries of one-bank bank holding companies (BHCs), and total BHC assets for subsidiaries of multibank BHCs. Local-market variables constructed as deposit-weighted averages for each market (MSA or non-MSA county) the bank serves. $P$-values are given for $t$-tests of differences in means and rank-sum tests for differences in medians. $N=57,077$.

\begin{tabular}{|c|c|c|c|c|}
\hline & & $\begin{array}{c}\text { Independent } \\
\text { banks and } \\
\text { one-bank BHC } \\
\text { subsidiaries } \\
\end{array}$ & $\begin{array}{c}\text { Multibank } \\
\text { BHC } \\
\text { subsidiaries } \\
\end{array}$ & $\begin{array}{l}P \text {-value of } \\
\text { difference }\end{array}$ \\
\hline Number of observations & & 39,540 & 17,537 & \\
\hline Total bank assets ( $\$$ billion) & $\begin{array}{l}\text { Mean } \\
\text { Median }\end{array}$ & $\begin{array}{l}0.101 \\
0.044\end{array}$ & $\begin{array}{l}0.796 \\
0.080\end{array}$ & $\begin{array}{l}(0.00) \\
(0.00)\end{array}$ \\
\hline $\begin{array}{l}\text { Total banking organization assets } \\
\text { (\$ billion) }\end{array}$ & $\begin{array}{l}\text { Mean } \\
\text { Median }\end{array}$ & $\begin{array}{l}0.101 \\
0.044\end{array}$ & $\begin{array}{l}9.699 \\
0.739\end{array}$ & $\begin{array}{l}(0.00) \\
(0.00)\end{array}$ \\
\hline Loans-to-assets ratio & $\begin{array}{l}\text { Mean } \\
\text { Median }\end{array}$ & $\begin{array}{l}0.526 \\
0.541\end{array}$ & $\begin{array}{l}0.565 \\
0.585\end{array}$ & $\begin{array}{l}(0.00) \\
(0.00)\end{array}$ \\
\hline Capital-asset ratio & $\begin{array}{l}\text { Mean } \\
\text { Median }\end{array}$ & $\begin{array}{l}0.098 \\
0.088\end{array}$ & $\begin{array}{l}0.090 \\
0.080\end{array}$ & $\begin{array}{l}(0.00) \\
(0.00)\end{array}$ \\
\hline Return on assets & $\begin{array}{l}\text { Mean } \\
\text { Median }\end{array}$ & $\begin{array}{l}0.008 \\
0.010\end{array}$ & $\begin{array}{l}0.011 \\
0.011\end{array}$ & $\begin{array}{l}(0.00) \\
(0.00)\end{array}$ \\
\hline $\begin{array}{l}\text { Local-market population } \\
\text { (thousands) }\end{array}$ & $\begin{array}{l}\text { Mean } \\
\text { Median }\end{array}$ & $\begin{array}{l}1,169 \\
0.398\end{array}$ & $\begin{array}{l}1,080 \\
0.766\end{array}$ & $\begin{array}{l}(0.00) \\
(0.00)\end{array}$ \\
\hline $\begin{array}{l}\text { Local-market per capita personal } \\
\text { income ( } \$ \text { thousands) }\end{array}$ & $\begin{array}{l}\text { Mean } \\
\text { Median }\end{array}$ & $\begin{array}{l}17.844 \\
17.203\end{array}$ & $\begin{array}{l}18.392 \\
17.855\end{array}$ & $\begin{array}{l}(0.00) \\
(0.00)\end{array}$ \\
\hline $\begin{array}{l}\text { Local-market concentration } \\
\text { (deposit Herfindahl) }\end{array}$ & $\begin{array}{l}\text { Mean } \\
\text { Median }\end{array}$ & $\begin{array}{l}0.342 \\
0.248\end{array}$ & $\begin{array}{l}0.304 \\
0.227\end{array}$ & $\begin{array}{l}(0.00) \\
(0.00)\end{array}$ \\
\hline Local-market MSA dummy & $\begin{array}{l}\text { Mean } \\
\text { Median }\end{array}$ & $\begin{array}{l}0.418 \\
0.000\end{array}$ & $\begin{array}{l}0.502 \\
1.000\end{array}$ & $\begin{array}{l}(0.00) \\
(0.00)\end{array}$ \\
\hline
\end{tabular}




\section{Table 2: Bank Panel Regressions}

OLS and fixed-effects panel regressions of bank characteristics-loans-to-assets ratio (LTA), capital-asset ratio (KA), and return on assets (ROA) — on a multibank bank holding company (MBHC) indicator variable, the logs of total bank assets and total banking organization assets, deposit-weighted measures of local-market characteristics, and an indicator for banks whose parent organizations include one or more nonbank subsidiaries. Regressions include year-fixed effects. Pooled data from 1990 to 1994. $N=57,077$. Robust standard errors in parentheses. ${ }^{* *}, * *$, and $*$ indicate statistical significance at the 1,5 , and 10 percent levels, respectively.

Panel A: Pooled OLS Regressions

\begin{tabular}{|c|c|c|c|}
\hline & LTA & KA & ROA \\
\hline $\mathrm{MBHC}$ indicator & $\begin{array}{l}0.0242 * * * \\
(0.0023)\end{array}$ & $\begin{array}{l}-0.0138 * * * \\
(0.0007)\end{array}$ & $\begin{array}{l}0.0007 * * * \\
(0.0001)\end{array}$ \\
\hline $\begin{array}{l}\text { Log (total bank } \\
\text { assets) }\end{array}$ & $\begin{array}{l}0.0169 * * * \\
(0.0009)\end{array}$ & $\begin{array}{l}-0.0114 * * * \\
(0.0003)\end{array}$ & $\begin{array}{l}0.0010^{* * * *} \\
(0.0001)\end{array}$ \\
\hline $\begin{array}{l}\text { Log (total banking } \\
\text { organization assets) }\end{array}$ & $\begin{array}{l}-0.0029 * * * \\
(0.0008)\end{array}$ & $\begin{array}{l}0.0040^{* * *} \\
(0.0002)\end{array}$ & $\begin{array}{c}0.0001 \\
(0.0000)\end{array}$ \\
\hline Local-market population & $\begin{array}{l}-0.0004 * * * \\
(0.0001)\end{array}$ & $\begin{array}{l}0.0001^{* * *} \\
(0.0000)\end{array}$ & $\begin{array}{l}-0.0001^{* * *} \\
(0.0000)\end{array}$ \\
\hline $\begin{array}{l}\text { Local-market per-capita } \\
\text { income }\end{array}$ & $\begin{array}{l}0.0045^{* * *} \\
(0.0001)\end{array}$ & $\begin{array}{l}0.0002 * * * \\
(0.0001)\end{array}$ & $\begin{array}{l}-0.0003^{* * *} \\
(0.0000)\end{array}$ \\
\hline $\begin{array}{l}\text { Local-market MSA } \\
\text { indicator }\end{array}$ & $\begin{array}{c}-0.0042 * \\
(0.0021)\end{array}$ & $\begin{array}{l}-0.0018 * * * \\
(0.0006)\end{array}$ & $\begin{array}{l}-0.0012 * * * \\
(0.0001)\end{array}$ \\
\hline $\begin{array}{l}\text { Local-market } \\
\text { concentration }\end{array}$ & $\begin{array}{l}-0.0777 * * * \\
(0.0034)\end{array}$ & $\begin{array}{c}0.0015 \\
(0.0010)\end{array}$ & $\begin{array}{l}0.0018^{* * *} \\
(0.0002)\end{array}$ \\
\hline $\begin{array}{l}\text { Parent has non-bank } \\
\text { subsidiary }\end{array}$ & $\begin{array}{l}0.0208 * * * \\
(0.0025)\end{array}$ & $\begin{array}{l}0.0022 * * * \\
(0.0001)\end{array}$ & $\begin{array}{l}-0.0008^{* * *} \\
(0.0001)\end{array}$ \\
\hline Constant & $\begin{array}{l}0.3457 * * * \\
(0.0083)\end{array}$ & $\begin{array}{l}0.1661^{* * *} \\
(0.0025)\end{array}$ & $\begin{array}{l}-0.0051^{* * *} \\
(0.0005)\end{array}$ \\
\hline$R^{2}$ & 0.077 & 0.063 & 0.115 \\
\hline
\end{tabular}




\section{Table 2: Bank Panel Regressions (continued)}

Panel B: Regressions with Bank-Fixed Effects

\begin{tabular}{lccc} 
& LTA & KA & ROA \\
\hline MBHC indicator & $0.0161^{* * *}$ & $-0.0060^{* * *}$ & $-0.0007^{* * *}$ \\
& $(0.0024)$ & $(0.0007)$ & $(0.0002)$ \\
Log (total bank & $0.0244^{* * *}$ & $-0.0463^{* * *}$ & $0.0022^{* * *}$ \\
assets) & $(0.0018)$ & $(0.0006)$ & $(0.0002)$ \\
Log (total banking & $-0.0049^{* * *}$ & $0.0019^{* * *}$ & $-0.0003^{* * *}$ \\
organization assets) & $(0.0009)$ & $(0.0003)$ & $(0.0000)$ \\
& $-0.0005^{* * *}$ & 0.0000 & $-0.0001^{*}$ \\
Local-market population & $(0.0001)$ & $(0.0000)$ & $(0.0000)$ \\
& $-0.0014^{* * *}$ & 0.0002 & $0.0002^{* * *}$ \\
Local-market per-capita & $(0.0005)$ & $(0.0001)$ & $(0.0000)$ \\
income & 0.0045 & -0.0004 & $-0.0008^{* * *}$ \\
Local-market MSA & $(0.0039)$ & $(0.0012)$ & $(0.0004)$ \\
indicator & $-0.0380^{* * *}$ & $-0.0014^{*}$ & $0.0009^{* * *}$ \\
Local-market & $(0.0813)$ & $(0.0007)$ & $(0.0002)$ \\
concentration & $0.3684^{* * *}$ & $0.5717^{* * *}$ & $-0.0139 * * *$ \\
Constant & $(0.0200)$ & $(0.0062)$ & $(0.0020)$ \\
\hline$R^{2}$ & 0.042 & 0.048 & 0.008 \\
\hline & & & \\
\hline
\end{tabular}




\section{Table 3: Bank Panel Regressions with Self-Selection}

Regressions of bank characteristics - loans-to-assets ratio (LTA), capital-asset ratio (KA), and return on assets (ROA) — on size, lending, and local-market characteristics using Heckman's method to control for self-selection. First-stage probit regression (Panel A) models MBHC affiliation as a function of current and lagged values of bank characteristics and the percent of all banks in the bank's state that are MBHC affiliates. Outcome regressions (Panel B) include a restricted set of the independent variables reported in Table 2 and indicator variables for each state. $N=43,578$. Robust standard errors in third column of Panel A and in parentheses in Panel B. ***,**, and * indicate statistical significance at the 1,5 , and 10 percent levels, respectively.

\section{Panel A: Probit Estimates of MBHC Affiliation}

Log (total bank assets)

Loans-to-assets ratio

Capital-asset ratio

Return on assets

Local-market population

Local-market per-capita income

Local-market concentration

Log (total bank assets) (1 lag)

Loans-to-assets ratio (1 lag)

Capital-asset ratio (1 lag)

Return on assets (1 lag)

Local-market population (1 lag)

Local-market per-capita income (1 lag)

Local-market concentration (1 lag)

Local-market MSA indicator

Percent of MBHC banks in state

Constant

\begin{tabular}{ccc} 
Coefficient & $\begin{array}{c}\text { Standard } \\
\text { error }\end{array}$ & $\begin{array}{c}\text { Marginal } \\
\text { effect }\end{array}$ \\
\hline 0.0450 & 0.0673 & 0.0153
\end{tabular}

$0.7122 * * * \quad 0.1392 \quad 0.2421$

$\begin{array}{lll}-1.119 & 0.8534 & -0.3806\end{array}$

$4.2895^{* * *} \quad 1.5220 \quad 1.4582$

$\begin{array}{lll}-0.0003 & 0.0018 & -0.0001\end{array}$

$\begin{array}{lll}-0.0062 & 0.0099 & -0.0021\end{array}$

$\begin{array}{lll}0.0119 & 0.0638 & 0.0040\end{array}$

$0.2951 * * * \quad 0.0674 \quad 0.1003$

$\begin{array}{lll}-0.2820 * * & 0.1410 & -0.0959\end{array}$

$\begin{array}{lll}-0.5328 & 0.8165 & -0.1811\end{array}$

$5.5157 * * * \quad 1.3864 \quad 1.9873$

$\begin{array}{lll}-0.0026 & 0.0018 & -0.0008\end{array}$

$\begin{array}{lll}0.0084 & 0.0101 & 0.0029\end{array}$

$\begin{array}{lll}0.0814 & 0.0551 & 3.0277\end{array}$

$\begin{array}{lll}0.0606^{* * *} & 0.0226 & 0.0207\end{array}$

$3.2660 * * * \quad 0.0688 \quad 1.1103$

$-5.6071 * * * \quad 0.1117$

Pseudo $R^{2}$

0.139 
Table 3: Bank Panel Regressions with Self-Selection (Continued)

Panel B: Outcome Regressions with Selection Correction

\begin{tabular}{|c|c|c|c|}
\hline & LTA & KA & ROA \\
\hline MBHC indicator & $\begin{array}{l}0.0234 * * * \\
(0.0021)\end{array}$ & $\begin{array}{l}-0.0104 * * * \\
(0.0009)\end{array}$ & $\begin{array}{c}-0.0002 \\
(0.0001)\end{array}$ \\
\hline $\begin{array}{l}\text { Log (total bank } \\
\text { assets) }\end{array}$ & $\begin{array}{l}-0.1361 * * * \\
(0.0023)\end{array}$ & $\begin{array}{l}0.0285^{* * *} \\
(0.0018)\end{array}$ & $\begin{array}{l}-0.0030 * * * \\
(0.0002)\end{array}$ \\
\hline $\begin{array}{l}\text { Log (total banking } \\
\text { organization assets) }\end{array}$ & $\begin{array}{l}-0.0014 \\
(0.0009)\end{array}$ & $\begin{array}{l}0.0039^{* * *} \\
(0.0006)\end{array}$ & $\begin{array}{c}-0.0000 \\
(0.0001)\end{array}$ \\
\hline Local-market population & $\begin{array}{l}0.0011 * * * \\
(0.0001)\end{array}$ & $\begin{array}{l}-0.0003^{* * *} \\
(0.0000)\end{array}$ & $\begin{array}{c}0.0000 \\
(0.0000)\end{array}$ \\
\hline $\begin{array}{l}\text { Local-market per-capita } \\
\text { income }\end{array}$ & $\begin{array}{l}0.0027 * * * \\
(0.0003)\end{array}$ & $\begin{array}{c}0.0000 \\
(0.0000)\end{array}$ & $\begin{array}{l}-0.0001 * * * \\
(0.0000)\end{array}$ \\
\hline $\begin{array}{l}\text { Local-market MSA } \\
\text { indicator }\end{array}$ & $\begin{array}{l}0.0022 * * * \\
(0.0021)\end{array}$ & $\begin{array}{l}-0.0047 * * * \\
(0.0010)\end{array}$ & $\begin{array}{l}-0.0012 * * * \\
(0.0001)\end{array}$ \\
\hline $\begin{array}{l}\text { Local-market } \\
\text { concentration }\end{array}$ & $\begin{array}{l}-0.0467 * * * \\
(0.0034)\end{array}$ & $\begin{array}{c}0.0105 \\
(0.0010)\end{array}$ & $\begin{array}{l}0.0009 * * * \\
(0.0002)\end{array}$ \\
\hline$\lambda$ & $\begin{array}{l}-0.5788^{* * *} \\
(0.0097)\end{array}$ & $\begin{array}{l}0.1603^{* * *} \\
(0.0088)\end{array}$ & $\begin{array}{l}-0.0164 * * * \\
(0.0002)\end{array}$ \\
\hline Constant & $\begin{array}{l}2.9707 * * * \\
(0.0486)\end{array}$ & $\begin{array}{l}-0.4837 * * * \\
(0.0363)\end{array}$ & $\begin{array}{l}0.0673 * * * \\
(0.0035)\end{array}$ \\
\hline
\end{tabular}




\section{Table 4: Bank Holding Company Summary Statistics}

Summary statistics for sample of publicly traded bank holding companies (BHCs), 1990 to 1994. The first row of each pair of rows gives the mean and the second row gives the median. Balance-sheet and income data are taken from Call Reports (Y-9C reports), valuation data from CRSP. Balance-sheet and income ratios are calculated for each $\mathrm{BHC}$ as asset-weighted averages of the ratios for its commercial bank subsidiaries. Tobin's $q$ is defined as the market value of equity divided by the book value of tangible equity.

\begin{tabular}{lcccccc}
\hline & \multicolumn{6}{c}{ Number of Bank Subsidiaries } \\
\cline { 2 - 7 } & All & 1 & $2-9$ & $10-19$ & $20-29$ & $30+$ \\
\cline { 2 - 7 } $\begin{array}{l}\text { Loans-to-assets } \\
\text { ratio }\end{array}$ & 0.6068 & 0.6022 & 0.6083 & 0.6029 & 0.6060 & 0.6480 \\
& 0.6259 & 0.6195 & 0.6303 & 0.6127 & 0.6147 & 0.6588 \\
Capital-asset & 0.0786 & 0.0797 & 0.0783 & 0.0780 & 0.0743 & 0.0745 \\
ratio & 0.0776 & 0.0786 & 0.0779 & 0.0761 & 0.0710 & 0.0742 \\
& & & & & & \\
Return on assets & 0.0077 & 0.0063 & 0.0083 & 0.0091 & 0.0091 & 0.0103 \\
& 0.0096 & 0.0092 & 0.0097 & 0.0102 & 0.0091 & 0.0105 \\
& & & & & & \\
Tobin's $q$ & 1.266 & 1.189 & 1.300 & 1.316 & 1.167 & 1.598 \\
& 1.244 & 1.100 & 1.306 & 1.367 & 1.280 & 1.624 \\
Number of bank & 5.4 & 1.0 & 4.1 & 13.6 & 23.2 & 46.0 \\
subsidiaries & 2 & 1 & 4 & 13 & 23 & 40 \\
& & & & & & \\
Number of states & 1.9 & 1.0 & 1.9 & 4.0 & 3.7 & 5.8 \\
& 1 & 1 & 1 & 3 & 3 & 5 \\
BHC total assets & 8.312 & 1.143 & 8.122 & 31.003 & 23.796 & 30.508 \\
(\$ billion) & 1.285 & 0.542 & 1.870 & 5.066 & 6.579 & 29.795 \\
$\begin{array}{l}\text { Assets per bank } \\
\text { subsidiary }\end{array}$ & 1.600 & 1.143 & 1.910 & 2.384 & 0.986 & 0.661 \\
(\$ billion) & 0.493 & 0.542 & 0.422 & 0.312 & 0.316 & 0.585 \\
$N$ & & & & & & \\
\hline & 1,321 & 492 & 657 & 100 & 32 & 40 \\
\hline
\end{tabular}




\section{Table 5: Bank Holding Company Panel Regressions}

Panel regressions of BHC characteristics-loans-to-assets ratio (LTA), capital-asset ratio (KA), return on assets (ROA), and market-to-book equity $(q)$ - on the log of the number of bank charters, log of the number of states in which the BHC operates, $\log$ of total assets, state economic conditions, and an indicator for BHCs with nonbank subsidiaries. Regressions include BHC-specific and time-fixed effects. Pooled data from 1990 to $1994 . N=1,321$. Standard errors in parentheses. ${ }^{* *}, * *$, and * indicate statistical significance at the 1,5 , and 10 percent levels, respectively.

\begin{tabular}{|c|c|c|c|c|c|c|c|c|}
\hline \multirow[b]{2}{*}{ Log (number of banks) } & \multicolumn{2}{|c|}{ LTA } & \multicolumn{2}{|c|}{$\mathrm{KA}$} & \multicolumn{2}{|c|}{$\mathrm{ROA}$} & \multicolumn{2}{|l|}{$q$} \\
\hline & $\begin{array}{l}0.012 * * \\
(0.005)\end{array}$ & $\begin{array}{c}0.007 \\
(0.006)\end{array}$ & $\begin{array}{l}-0.000 \\
(0.001)\end{array}$ & $\begin{array}{l}-0.000 \\
(0.001)\end{array}$ & $\begin{array}{l}-0.003 * * * \\
(0.001)\end{array}$ & $\begin{array}{l}-0.002 * * \\
(0.001)\end{array}$ & $\begin{array}{l}-0.099 * * * \\
(0.031)\end{array}$ & $\begin{array}{c}-0.059 * \\
(0.034)\end{array}$ \\
\hline Log (number of states) & 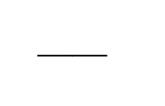 & $\begin{array}{l}0.029^{* *} \\
(0.012)\end{array}$ & & $\begin{array}{c}-0.001 \\
(0.002)\end{array}$ & & $\begin{array}{l}-0.005 * * * \\
(0.001)\end{array}$ & & $\begin{array}{l}-0.209 * * * \\
(0.068)\end{array}$ \\
\hline Log (total assets) & $\begin{array}{c}0.001 \\
(0.010)\end{array}$ & $\begin{array}{l}-0.004 \\
(0.010)\end{array}$ & $\begin{array}{l}-0.018 * * * \\
(0.002)\end{array}$ & $\begin{array}{l}-0.018 * * * \\
(0.002)\end{array}$ & $\begin{array}{l}-0.003^{* *} \\
(0.001)\end{array}$ & $\begin{array}{c}-0.002 \\
(0.001)\end{array}$ & $\begin{array}{l}-0.025 \\
(0.060)\end{array}$ & $\begin{array}{c}0.013 \\
(0.061)\end{array}$ \\
\hline Economic conditions & $\begin{array}{l}-0.391 * * * \\
(0.148)\end{array}$ & $\begin{array}{l}-0.369^{* *} \\
(0.148)\end{array}$ & $\begin{array}{c}-0.039 \\
(0.027)\end{array}$ & $\begin{array}{c}-0.042 \\
(0.028)\end{array}$ & $\begin{array}{l}0.039^{* *} \\
(0.018)\end{array}$ & $\begin{array}{l}0.036^{* *} \\
(0.018)\end{array}$ & $\begin{array}{r}1.539 * \\
(0.870)\end{array}$ & $\begin{array}{c}1.377 \\
(0.867)\end{array}$ \\
\hline $\begin{array}{l}\text { Indicator for nonbank } \\
\text { subsidiaries }\end{array}$ & $\begin{array}{l}0.023 * * * \\
(0.006)\end{array}$ & $\begin{array}{l}0.023 * * * \\
(0.006)\end{array}$ & $\begin{array}{c}0.001 \\
(0.001)\end{array}$ & $\begin{array}{c}0.001 \\
(0.001)\end{array}$ & $\begin{array}{c}0.001 \\
(0.001)\end{array}$ & $\begin{array}{c}0.001 \\
(0.001)\end{array}$ & $\begin{array}{l}-0.016 \\
(0.035)\end{array}$ & $\begin{array}{l}-0.019 \\
(0.035)\end{array}$ \\
\hline Constant & $\begin{array}{l}0.581 * * * \\
(0.147)\end{array}$ & $\begin{array}{l}0.650 * * * \\
(0.149)\end{array}$ & $\begin{array}{l}0.346^{* * *} \\
(0.027)\end{array}$ & $\begin{array}{l}0.343 * * * \\
(0.028)\end{array}$ & $\begin{array}{l}0.050 * * * \\
(0.018)\end{array}$ & $\begin{array}{c}0.039 \\
(0.018)\end{array}$ & $\begin{array}{l}1.812^{* *} \\
(0.862)\end{array}$ & $\begin{array}{c}1.313 \\
(0.873)\end{array}$ \\
\hline$R^{2}$ & 0.024 & 0.026 & 0.091 & 0.091 & 0.001 & 0.001 & 0.056 & 0.048 \\
\hline
\end{tabular}




\section{Table 6: Marginal Effects of Adding Bank Charters}

Panel regressions of BHC characteristics - loans-to-assets ratio (LTA), capital-asset ratio (KA), return on assets (ROA), and market-to-book equity $(q)$ - on the log of total assets, an index of state economic conditions, an indicator for BHCs with nonbank subsidiaries, and indicator variables $D$ corresponding to 2-4 bank charters, 5-9 bank charters, 10-14 bank charters, 15-19 bank charters, 20-24 bank charters, 25-29 bank charters, and 30 or more bank charters. (Only the indicators $D$ are reported below.) Robust standard errors in parentheses. Regressions include BHC-specific and time-fixed effects. Pooled data from 1990 to $1994 . N=1,321 . * * *, * *$, and $*$ indicate statistical significance at the 1,5 , and 10 percent levels, respectively.

\begin{tabular}{|c|c|c|c|c|c|}
\hline & $\underline{\text { LTA }}$ & $\underline{\mathrm{KA}}$ & $\underline{\mathrm{ROA}}$ & $q$ & $\begin{array}{c}\text { Observations } \\
\text { with } D=1\end{array}$ \\
\hline 2-4 bank charters & $\begin{array}{c}0.009 \\
(0.007)\end{array}$ & $\begin{array}{c}-0.002 \\
(0.001)\end{array}$ & $\begin{array}{l}-0.003 * * * \\
(0.001)\end{array}$ & $\begin{array}{c}-0.150 * * * \\
(0.043)\end{array}$ & 435 \\
\hline 5-9 bank charters & $\begin{array}{c}0.018^{*} \\
(0.011)\end{array}$ & $\begin{array}{c}-0.000 \\
(0.002)\end{array}$ & $\begin{array}{l}-0.005^{* * *} \\
(0.001)\end{array}$ & $\begin{array}{c}-0.160 * * \\
(0.063)\end{array}$ & 222 \\
\hline 10-14 bank charters & $\begin{array}{c}0.015 \\
(0.016)\end{array}$ & $\begin{array}{c}0.001 \\
(0.003)\end{array}$ & $\begin{array}{l}-0.006^{* * *} \\
(0.002)\end{array}$ & $\begin{array}{c}-0.151^{*} \\
(0.089)\end{array}$ & 65 \\
\hline 15-19 bank charters & $\begin{array}{c}0.015 \\
(0.016)\end{array}$ & $\begin{array}{c}-0.001 \\
(0.003)\end{array}$ & $\begin{array}{l}-0.007 * * * \\
(0.003)\end{array}$ & $\begin{array}{c}-0.143 \\
(0.106)\end{array}$ & 35 \\
\hline 20-24 bank charters & $\begin{array}{c}0.037^{*} \\
(0.021)\end{array}$ & $\begin{array}{c}0.001 \\
(0.004)\end{array}$ & $\begin{array}{l}-0.007^{* *} \\
(0.003)\end{array}$ & $\begin{array}{c}-0.213^{*} \\
(0.127)\end{array}$ & 21 \\
\hline 25-29 bank charters & $\begin{array}{c}0.032 \\
(0.020)\end{array}$ & $\begin{array}{c}0.000 \\
(0.004)\end{array}$ & $\begin{array}{l}-0.007^{* *} \\
(0.003)\end{array}$ & $\begin{array}{l}-0.348^{* * *} \\
(0.129)\end{array}$ & 11 \\
\hline 30 or more bank charters & $\begin{array}{c}0.032 \\
(0.020)\end{array}$ & $\begin{array}{c}0.002 \\
(0.006)\end{array}$ & $\begin{array}{l}-0.009^{* *} \\
(0.004)\end{array}$ & $\begin{array}{c}-0.371^{* *} \\
(0.187)\end{array}$ & 40 \\
\hline$R^{2}$ & 0.071 & 0.094 & 0.001 & 0.067 & \\
\hline
\end{tabular}




\section{Table 7: BHC Panel Regressions with Instrumental Variables}

Instrumental-variables regressions of BHC characteristics - loans-to-assets ratio (LTA), capital-asset ratio (KA), return on assets (ROA), and market-to-book equity $(q)$ - on the log of the number of bank charters, log of the number of states in which the BHC operates, log of total assets, state economic conditions, and an indicator for BHCs with nonbank subsidiaries. Log (number of banks) is instrumented by the percentage of BHC assets in states permitting statewide branching in the previous year. Regressions include BHC-specific and time-fixed effects. Pooled data from 1990 to $1994 . N=1,321$. Standard errors in parentheses. $* * *, * *$, and $*$ indicate statistical significance at the 1,5 , and 10 percent levels, respectively.

\begin{tabular}{|c|c|c|c|c|c|c|c|c|}
\hline \multirow[b]{2}{*}{$\log$ (number of banks) } & \multicolumn{2}{|c|}{ LTA } & \multicolumn{2}{|c|}{$\mathrm{KA}$} & \multicolumn{2}{|c|}{ ROA } & \multicolumn{2}{|l|}{$q$} \\
\hline & $\begin{array}{c}0.042 \\
(0.050)\end{array}$ & $\begin{array}{c}0.042 \\
(0.034)\end{array}$ & $\begin{array}{l}-0.040 * * * \\
(0.015)\end{array}$ & $\begin{array}{l}-0.028 * * * \\
(0.008)\end{array}$ & $\begin{array}{l}-0.007 \\
(0.007)\end{array}$ & $\begin{array}{c}-0.008 * \\
(0.005)\end{array}$ & $\begin{array}{l}-2.425 * * * \\
(0.727)\end{array}$ & $\begin{array}{l}-1.753 * * * \\
(0.362)\end{array}$ \\
\hline Log (number of states) & 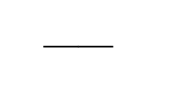 & $\begin{array}{l}-0.001 \\
(0.028)\end{array}$ & & $\begin{array}{l}0.019 * * * \\
(0.007)\end{array}$ & . & $\begin{array}{l}-0.001 \\
(0.004)\end{array}$ & & $\begin{array}{l}1.102 * * * \\
(0.299)\end{array}$ \\
\hline Log (total assets) & $\begin{array}{c}-0.018 \\
(0.015)\end{array}$ & $\begin{array}{l}-0.018 * * \\
(0.008)\end{array}$ & $\begin{array}{l}0.008 * \\
(0.004)\end{array}$ & $\begin{array}{l}-0.001 \\
(0.002)\end{array}$ & $\begin{array}{c}0.003 \\
(0.002)\end{array}$ & $\begin{array}{l}0.003 * * * \\
(0.001)\end{array}$ & $\begin{array}{l}0.936^{* * * *} \\
(0.219)\end{array}$ & $\begin{array}{l}0.475 * * * \\
(0.090)\end{array}$ \\
\hline Economic conditions & $\begin{array}{l}-0.471 * * * \\
(0.167)\end{array}$ & $\begin{array}{l}-0.472 * * * \\
(0.117)\end{array}$ & $\begin{array}{c}-0.001 \\
(0.048)\end{array}$ & $\begin{array}{c}0.044 \\
(0.027)\end{array}$ & $\begin{array}{c}0.015 \\
(0.022)\end{array}$ & $\begin{array}{c}0.012 \\
(0.016)\end{array}$ & $\begin{array}{c}0.714 \\
(2.422)\end{array}$ & $\begin{array}{c}1.855 \\
(1.251)\end{array}$ \\
\hline $\begin{array}{l}\text { Indicator for nonbank } \\
\text { subsidiaries }\end{array}$ & $\begin{array}{l}0.020 * * * \\
(0.006)\end{array}$ & $\begin{array}{l}0.020 * * * \\
(0.005)\end{array}$ & $\begin{array}{c}-0.003 * \\
(0.002)\end{array}$ & $\begin{array}{l}0.004 * * * \\
(0.002)\end{array}$ & $\begin{array}{l}0.002 * * \\
(0.001)\end{array}$ & $\begin{array}{c}0.002 \\
(0.003)\end{array}$ & $\begin{array}{l}-0.014 \\
(0.082)\end{array}$ & $\begin{array}{c}0.028 \\
(0.058)\end{array}$ \\
\hline Constant & $\begin{array}{l}0.821 * * * \\
(0.171)\end{array}$ & $\begin{array}{l}0.820 * * * \\
(0.115)\end{array}$ & $\begin{array}{c}0.008 \\
(0.050)\end{array}$ & $\begin{array}{l}0.105 * * * \\
(0.027)\end{array}$ & $\begin{array}{c}-0.031 \\
(0.015)\end{array}$ & $\begin{array}{l}-0.020 * * \\
(0.021)\end{array}$ & $\begin{array}{l}-9.694 * * * \\
(4.484)\end{array}$ & $\begin{array}{l}-4.239 * * * \\
(1.235)\end{array}$ \\
\hline
\end{tabular}




\section{Table 8: The Cost of Diversity}

Panel regressions of market-to-book equity $(q)$ on the log of the number of bank charters, log of the number of states in which the BHC operates, log of total assets, state economic condition, and three measures of intra-firm diversity: the within-BHC standard deviations of bank subsidiary size, bank subsidiary capitalization, and bank subsidiary lending. Regressions include BHC-specific and time-fixed effects. The second set of regressions uses the percentage of BHC assets in states permitting statewide branching in the previous year as an instrument for the number of banks. Sample includes multibank BHCs only. Pooled data from 1990 to 1994. $N=819$. Standard errors in parentheses. $* * * * *$, and $*$ indicate statistical significance at the 1,5 , and 10 percent levels, respectively.

\begin{tabular}{|c|c|c|c|c|}
\hline \multirow[b]{2}{*}{$\begin{array}{l}\text { Log (number of } \\
\text { banks) }\end{array}$} & \multicolumn{2}{|c|}{ Fixed effects } & \multicolumn{2}{|c|}{ IV } \\
\hline & $\begin{array}{c}-0.016 \\
(0.046)\end{array}$ & $\begin{array}{c}-0.002 \\
(0.046)\end{array}$ & $\begin{array}{l}-2.246 \\
(1.675)\end{array}$ & $\begin{array}{c}-1.696^{*} \\
(0.886)\end{array}$ \\
\hline $\begin{array}{l}\text { Log (number of } \\
\text { states) }\end{array}$ & - & $\begin{array}{l}-0.166^{* *} \\
(0.078)\end{array}$ & - & $\begin{array}{c}0.269 \\
(0.248)\end{array}$ \\
\hline Log (total assets) & $\begin{array}{c}-0.128 \\
(0.078)\end{array}$ & $\begin{array}{c}-0.086 \\
(0.080)\end{array}$ & $\begin{array}{l}1.168 \\
(0.799)\end{array}$ & $\begin{array}{l}0.826 * * \\
(0.367)\end{array}$ \\
\hline $\begin{array}{l}\text { Economic condi- } \\
\text { tions }\end{array}$ & $\begin{array}{c}1.098 \\
(1.029)\end{array}$ & $\begin{array}{l}1.007 \\
(1.026)\end{array}$ & $\begin{array}{c}2.422 \\
(2.570)\end{array}$ & $\begin{array}{c}3.144 * \\
(1.678)\end{array}$ \\
\hline $\begin{array}{l}\text { Std. dev. (bank } \\
\text { size) }\end{array}$ & $\begin{array}{c}-0.080 \\
(0.579)\end{array}$ & $\begin{array}{c}-0.263 \\
(0.583)\end{array}$ & $\begin{array}{l}-1.260 \\
(0.971)\end{array}$ & $\begin{array}{c}-0.900^{*} \\
(0.484)\end{array}$ \\
\hline $\begin{array}{l}\text { Std. dev. (bank } \\
\text { capital-asset ratio) }\end{array}$ & $\begin{array}{c}0.076 \\
(0.190)\end{array}$ & $\begin{array}{c}0.123 \\
(0.190)\end{array}$ & $\begin{array}{l}-0.053 \\
(0.374)\end{array}$ & $\begin{array}{c}-0.098 \\
(0.315)\end{array}$ \\
\hline $\begin{array}{l}\text { Std. dev. (bank } \\
\text { lending) }\end{array}$ & $\begin{array}{c}-0.452 * \\
(0.249)\end{array}$ & $\begin{array}{c}-0.457 * \\
(0.248)\end{array}$ & $\begin{array}{c}0.518 \\
(0.832)\end{array}$ & $\begin{array}{c}0.290 \\
(0.525)\end{array}$ \\
\hline Constant & $\begin{array}{l}2.847 * * \\
(1.129)\end{array}$ & $\begin{array}{l}2.300 * * \\
(1.154)\end{array}$ & $\begin{array}{r}-12.290 \\
(8.888)\end{array}$ & $\begin{array}{l}-8.359 * * \\
(4.053)\end{array}$ \\
\hline$R^{2}$ & 0.097 & 0.089 & & \\
\hline
\end{tabular}




\section{Notes}

${ }^{1}$ The diversification-discount literature in empirical corporate finance generally treats market valuations as unbiased estimates of expected future cash flows, such that $q$ ratios measure efficiency rather than market perceptions or bias.

${ }^{2}$ A one-bank bank holding company is a holding company with a single commercial bank subsidiary.

${ }^{3}$ As in the diversification discount literature we interpret profitability and market value as efficiency measures. The lower $q$ ratios of multi-unit BHCs mean either that investors (correctly) perceive them to be less efficient than more focused BHC, or that investors believe they cannot accurately evaluate the behavior and characteristics of complex organizations.

${ }^{4}$ Riegle-Neal does not eliminate all interstate branching restrictions, however. It limits the total amount of bank and thrift deposits a banking organization may reach by merger to 30 percent in a single state and 10 percent nationwide.

${ }^{5}$ Bank holding companies have considerable discretion in allocating capital and liquidity within the firm. There are important restrictions, however, that are unique to banking. First, Federal Reserve regulations require each bank subsidiary to maintain adequate capital reserves ( 5 percent of total assets). Second, the Bank Holding Company Act's "source of strength doctrine" requires the BHC to provide downstream capital to inadequately capitalized subsidiaries, limiting loser-sticking. Third, sections of the Federal Reserve Act restrict inter-subsidiary transfers of dividends, fees, and assets to ten percent of the subsidiary's total capital. (See Houston, James, and Marcus, 1997, for a more detailed description of these restrictions.)

${ }^{6}$ In an alternative specification we control for local-market conditions by including characteristics of the loan portfolio such as agricultural and real-estate lending to total lending, loan-loss provisions to total loans, and the like. These attributes reflect lending opportunities in local markets but are potentially endogenous, so we rely mainly on the specification reported in the text. The qualitative results from the 
alternative specification are very close to those reported in Tables 2 and 3.

${ }^{7}$ Nonbank subsidiaries are defined as finance companies, investment companies, securities brokers or dealers, agreement corporations, data processing servicers, Edge Act Corporations, and agreement corporations.

${ }^{8}$ To check that our results are robust to additional across-bank differences in the banking environment we experimented with additional control variables, such as indicator variables for cross-state differences in the timing of deregulation (see below for further details on these differences) and indicators for each state. The results (not reported here) were essentially the same as those reported in Table 2.

${ }^{9}$ Evidence that internal capital markets can reduce frictions between banks and suppliers of capital comes from studies of secondary markets for loans. Demsetz (2000) shows that MBHC subsidiaries are more likely to engage in both loan sales and loan purchases than banks that are not part of a holding company. For sales and purchases between banks within the same holding company, there are at least two reasons why MBHC subsidiaries would be more active in the secondary market for loans. If the subsidiaries are acting independently, then membership in the same holding company makes it easier to develop a reputation for truthful disclosure, helping to overcome the adverse-selection problem associated with such transactions. Alternatively, the holding company itself could be acting as a single agent, using the loan sale to shift resources from one part of the organization to another. Cebenoyen and Strahan (2000) show that participation in the loan sales market can be an alternative to access to internal capital markets for managing credit risk. They report that banks that engage in loan sales and purchases do more risky lending while holding less capital than other banks, even controlling for the bank's access to internal capital markets.

${ }^{10}$ SunTrust Bank's 2000 Annual Report notes that its recent consolidation of 28 separate bank charters into a single charter permits "the ability to uniformly conduct banking transactions — such as accessing account information or cashing a check — anywhere in the SunTrust system. Under our old multibank 
structure, individual SunTrust 'banks' often had different product features or customer procedures, in some cases mandated by legal or regulatory requirements that varied from state to state." Moreover, "[o]perating as one bank ... permits many back-office and administrative functions to be streamlined."

${ }^{11}$ Other papers using a $q$ ratio similar to ours to measure bank performance include Keeley (1990), Demsetz, Saidenberg, and Strahan (1996, 1998), Galloway, Lee, and Roden (1997), and Adams and Mehran (2002).

${ }^{12}$ Strahan and Weston (1998), studying the effects of bank consolidation on small-business lending, use average bank subsidiary size as a measure of BHC organizational complexity (along with other measures, such as the numbers of subsidiaries and states). They find that the effect of subsidiary size on small-business lending is positive for smaller BHCs but negative for larger BHCs.

${ }^{13}$ To further compare our findings with those in the diversification-discount literature, we considered computing an adjusted $q$ for our MBHCs analogous to the industry-adjusted $q$ used in the diversification discount literature (the difference between a diversified firm's $q$ and the weighted average $q$ of a portfolio of single-industry firms matching the diversified firm's activities). For us, this would involve constructing matched portfolios, for each of our MBHCs, of independent banks or members of one-bank bank holding companies operating in the same states as the MBHC's member banks, then subtracting the $q$ of this portfolio from the $q$ of the MBHC (similar to the analysis in Klein and Saidenberg, 2000). Unfortunately, there are too few publicly traded independent banks or members of one-bank BHCs to facilitate such a comparison using $q$.

${ }^{14}$ Incidentally, the BHCs with the largest numbers of subsidiaries were not the money-center BHCs but the large regional banks like Banc One, Norwest, and Boatmen's Bancshares.

${ }^{15}$ Many recent papers in the diversification-discount literature attempt to grapple with this kind of endogeneity by using self-selection and instrumental-variables models and by examining the characteristics of diversified firms before they became diversified. See Chevalier (2000), Campa and Kedia (2002), 
Graham, Lemmon, and Wolf (2002), and Villalonga (2004) for examples.

${ }^{16}$ As with the results reported in Table 5, we experimented with subsamples that excluded the largest and smallest BHCs, money-center BHCs, and so on. Again, the coefficient estimates and significance levels were close to those reported in Table 7.

${ }^{17}$ The Gramm-Leach-Bliley Act of 1999, loosening restrictions on banks' non-bank activities, also contributed to the rise in branches, as branches can be used to distribute the banks' insurance and securities products.

${ }^{18}$ The Contracting and Organizations Research Institute maintains a database of contractual and organizational information, mostly derived from EDGAR, for a large set of US companies. The database is available at http://cori.missouri.edu. 